\title{
Shape modification of Ahmed body to reduce drag coefficient and determination of turbulence model
}

\author{
Ahmed modelinin sürüikleme katsayısını azaltmak için şekil modifikasyonu ve \\ türbülans modelinin belirlenmesi
}

\author{
Ahmet Şumnu ${ }^{1, *}$ \\ ${ }^{1}$ Department of Aerospace Engineering, İskenderun Technical University, 31200, Hatay, Turkey,
}

\begin{abstract}
In this study, the aerodynamic analysis of Ahmed body which is generic automobile model is performed to determine convenient turbulence model and reduce drag coefficient by modifying shape of model. For this purpose, Computational Fluid Dynamics (CFD) analysis is carried out using different turbulence models that are SpalartAllmaras, (Shear Stress Transport) SST k- $\omega$, Standard k- $\varepsilon$, Realizable k- $\varepsilon$, (Re-Normalisation Group) RNG k- $\varepsilon$ turbulence models. The results are compared with experimental data that is available in literature. The results show that RNG $\mathrm{k}-\varepsilon$ turbulence model gives superior performance when compared with other models. In order to reduce drag coefficient, the upper region of sides of model is rounded by applying fixed blend radius with $25 \mathrm{~mm}$. The smooth surface can provide high performance in point of aerodynamics. CFD solution is then repeated for the modified model and the result show that drag coefficient value reduces about $6 \%$. In addition, the second modification is performed by applying fixed blend radius with rounded both upper sides and rear underside of body and chamfer with $50 \mathrm{~mm}$ is also applied to rear sides of body. However, drag coefficient reduction level is approximately same with first modified model. The pressure coefficient contours and velocity streamlines are presented to show results for baseline and modified bodies.
\end{abstract}

Keywords: Ahmed body, Drag coefficient, Shape modification, Turbulence model.

\section{Introduction}

Automotive industry has an important position in the world and continuously develops day by day. The economy is most crucial issue for all industry. Therefore, the engineers try to design and improve economic vehicles. The reduction of fuel consumption can be considered an important task for designer that should find the optimum design for an automobile. It can be stated that the aerodynamic is the most effective factor for fuel consumption of a vehicle. Therefore, the external shape of vehicle should be analyzed by point of aerodynamic for calculation of drag coefficient or force.

\section{Özet}

$\mathrm{Bu}$ çalışmada, uygun türbülans modelini belirlemek ve şekil modifikasyonu yaparak sürükleme katsayısını azaltmak için jenerik otomobil modeli olan Ahmed modelinin aerodinamik analizi yapılmıştır. $\mathrm{Bu}$ amaçla, Hesaplamalı Akışkanlar Dinamiği (HAD) analizi, SpalartAllmaras, (Shear Stress Transport) SST k-omega, Standard k-epsilon, Realizable k-epsilon, (Re-Normalization Group) RNG k-epsilon türbülans modelleri olmak üzere beş farklı türbülans modelleri kullanılarak gerçekleştirildi. Sonuçlar literatürde bulunan deneysel verilerle karşılaştırıldı. RNG k-epsilon türbülans modelinin diğer modellere göre daha üstün performans gösterdiği gözlemlendi. Sürükleme katsayısını düşürmek için birinci modifikasyonda modelin üst yan bölgeleri $25 \mathrm{~mm}$ sabit yarıçap uygulanarak yuvarlatılmıştır. Pürüzsüz yüzey, aerodinamik açıdan yüksek performans sağlayabilir. HAD çözümü değiştirilen model için tekrarlandı ve sonuç, sürükleme katsayısı değerinin yaklaşık \% 6 oranında azaldığını göstermektedir. Ayrıca gövdenin her iki üst ve arka alt tarafi sabit yarıçap ile yuvarlatılmış ve gövdenin arka taraflarına da $50 \mathrm{~mm}$ pah uygulanarak ikinci modifikasyon yapılmıștır. Ancak, sürükleme katsayısı azalma seviyesi, ilk değiștirilen modelle yaklaşık olarak aynıdır. Basınç katsayısı konturları ve hız akış çizgileri, sonuçları göstermek üzere sunulmuştur.

Anahtar kelimeler: Ahmed modeli, Sürükleme katsayısı, Şekil modifikasyonu, Türbülans model.

Aerodynamic analysis can be performed experimentally in a wind tunnel. However, experimental studies may be more time consuming and costly than numerical simulation method. CFD method can be used to solve flow physics. The Navier-Stokes equations are used when flow solution is performed. In addition, turbulence models are used to obtain accurate results and simulate the flowfield closer to reality since the flow around a vehicle is generally turbulent. Thus, the numerical simulation provides advantages to the researcher in point of saving time and reducing the cost. The previous studies related with aerodynamics of Ahmed body are presented in the following paragraphs.

\footnotetext{
* Sorumlu yazar / Corresponding author, e-posta / e-mail: ahmet.sumnu@iste.edu.tr (A. Şumnu)

Geliș / Recieved: 13.02.2021 Kabul / Accepted: 09.06.2021 Yayımlanma / Published: 27.07.2021

doi: 10.28948/ngumuh.879584
} 
Ahmed et al. [1] presented the simplified ground vehicle type of bluff body to analyze the time average wake structure as experimentally. Flow field was observed different slant angle and it was concluded that most of drag force stemmed from rear end of the body. The other similar study that related with wake structure of typical vehicle body was presented by Ahmed [2]. In this paper, different shape of vehicle characteristics that are Estate, Fastback and Notchback were analyzed in point of wake structure in a wind tunnel. Same author also presented another similar paper changing slant angle between $0^{\circ}$ and $40^{\circ}$ and investigated pressure distribution, correlation of wake structure with drag and vortex motion in wake [3].

Khan and Umale [4] was proposed aerodynamic analysis of Ahmed body using Ansys Fluent. They implemented the study in two separate cases changing front of the body radius (R80 and R120) and ground clearance (20 mm and $40 \mathrm{~mm}$ ). Numerical noise in CFD based solution was proposed for road vehicle by Gilkeson et al. [5]. This study Moving Least Squares (MLS) metamodels were constructed and it was observed that the metamodels deals with numerical noise. Meile et al. [6] was investigated Ahmed body in point of aerodynamic behavior and performed numerical simulation and experimental study. The aerodynamic investigation was performed using Large Eddy Simulation (LES) method at high Reynolds-number for flow over Ahmed body by Östh et al. [7]. An experimental study related with unsteady wake of Ahmed body was presented by Volpe et al. [8]. Yakkundi and Mantha [9] performed a study to analyze the CFD solution of car model. The experimental and CFD solution results of Ahmed body was used to validate for generated image model car. Thabet and Thabit [10] presented CFD simulation study using Ahmed body model with $40^{\circ}$ slant angle. The results were validated by comparing with available experimental result.

Tunay et al. [11] investigated the crosswind sensitivity that affects the ground vehicles driving performance. The study was conducted using Ahmed body vehicle model with specified yaw angles $\left(0^{\circ}-15^{\circ}\right.$ degrees $)$ and rear slant angle at $25^{\circ}$ and $35^{\circ}$. The results of the study, the authors concluded that the rear slanted surface and rear vertical surface are crucial in point of flow dynamics since turbulence rate and velocity fluctuations effectively high at upper and lower zone of shear layers. Another crosswind study was presented for heavy ground vehicles since their center of gravity is high and they have high lateral surface area. Therefore, the heavy ground vehicles can be encountered in danger of rolling over. Hence, in thus study, aerodynamic and vehicle dynamics were investigated roll and lateral dynamics of heavy ground vehicle under subjected of crosswind [12]. The aerodynamic study related with simplified ground vehicle was also presented using particle image velocimetry (PIV) technique. Flow characteristic was investigated changing the slant angle of Ahmed body [13]. The similar study related with crosswind and headwind of the Ahmed body was presented by Zafer and Haskaraman [14]. In this study, incompressible unsteady aerodynamic analysis was performed and compared with experimental study that is available in the literature. Bello-Millan et al. [15] also conducted experimental study using Ahmed body to determine yaw angle effects on the drag coefficient. The results of the study it was observed that the drag force was increase when yaw angle was between $0^{\circ}$ and $60^{\circ}$ and remains constant between $60^{\circ}$ and $75^{\circ}$ and the drag coefficient was than increase up to $90^{\circ}$.

Chovet et al. [16] presented a paper that aims reduction drag force applying sliding mode control (SCM) using square-back Ahmed body. In this study, continuous blowing and controlled blowing applied at different frequencies were applied back of the body to reduce drag force. Drag force was significantly reduced applying proposed approach. Park et al. [17] proposed to use an active flow control technology for increasing aerodynamic efficiency of Ahmed body. Jet actuator was used placing back of the body and it was concluded that reduction of drag force was provided for Ahmed body with $25^{\circ}$ slant angle however, drag force was increase for $35^{\circ}$ slant angle. Banga et al. [18] also studied on rear slant angle of Ahmed body to investigate aerodynamic efficiency that can be determined using drag and lift force. The appropriate rear slant angle was found $7.5^{\circ}$ since minimum drag coefficient was obtained at this angle.

In this study, CFD simulation of generic Ahmed body is performed using five different turbulence models. The purpose of this study is to show which turbulence model gives accurate results and simulate the flow closer to reality. In addition, the Ahmed body model is modified to reduce drag coefficient by changing some geometric parameter. The upper region of sides of model is rounded by applying fixed blend radius with $25 \mathrm{~mm}$. The results of study show that drag level of Ahmed body model reduce about 6\%. The second modification is performed by applying fixed blend radius with rounded both upper sides and rear underside of body and chamfer with $50 \mathrm{~mm}$ is also applied to rear sides of body. Pressure coefficient contours and velocity streamlines are presented for all turbulence models and modified models.

\section{Flow solver}

\subsection{Governing equation}

The Navier-Stokes equations are used to describe the flow fluids. The continuity and momentum equations are available in the Navier-Stokes equations. The threedimensional, unsteady, compressible flow can be written following Equations (1) and (2)

$$
\text { Continuity Equation: } \frac{\partial \rho}{\partial t}+\vec{\nabla}(\rho \vec{V})=0
$$

The Navier-Stokes equation in $\mathrm{x}$-direction can be written as:

$$
\frac{\partial(\rho u)}{\partial t}+\nabla(\rho u V)=-\frac{\partial P}{\partial x}+\frac{\partial \tau_{x x}}{\partial x}+\frac{\partial \tau_{y x}}{\partial y}+\frac{\partial \tau_{z x}}{\partial z}+\rho f x
$$

Drag coefficient is an important characteristic of aerodynamic of vehicles. It can be calculated using the following Equation (3). 


$$
C_{D}=\frac{D}{\frac{1}{2} \rho V_{\infty}^{2} S}
$$

\subsection{Turbulence model}

The selection of convenient turbulence model is important issue to simulate accurately flow field for vehicles since the flow of vehicles is generally turbulent. In this study, five different turbulence models are used to simulate the flow physics and consider suitable model for Ahmed body model. The turbulence models used for simulation are presented in the following sub-sections.

\subsubsection{Spalart-Allmaras turbulence model}

The Spalart-Allmaras turbulence model is a one equation model and it is a transport equation for eddy viscosity. It requires low power and computational time during solution of problem. This turbulence model is suitable to apply transonic flow and the flow with adverse pressure gradient. The transport equation of Spalart-Allmaras turbulence model is written as follow Equation (4) [19].

$$
\begin{array}{r}
\frac{D \widetilde{v}}{D t}=\frac{1}{\sigma}\left[\nabla((v+\widetilde{v}) \nabla \widetilde{v})+c_{b 2}(\nabla \widetilde{v})^{2}\right]+c_{b 1} \tilde{S} \widetilde{v}\left(1-f_{t 2}\right) \\
-\left[c_{w 1} f_{w}-\frac{c_{1}}{\kappa^{2}} f_{t 2}\right]\left[\frac{\widetilde{v}}{d}\right]^{2}+f_{t 1}(\Delta q)^{2}
\end{array}
$$

From Equation $\frac{1}{\sigma}\left[\nabla((v+\widetilde{v}) \nabla \widetilde{v})+c_{b 2}(\nabla \widetilde{v})^{2}\right]$ is the diffusion term, and $c_{\mathrm{b} 1} \widetilde{\mathrm{S}} \widetilde{\mathrm{v}}\left(1-\mathrm{f}_{\mathrm{t} 2}\right)$ is the production term and $\left[c_{\mathrm{w} 1} f_{\mathrm{w}}-\frac{\mathrm{c}_{1}}{\kappa^{2}} \mathrm{f}_{\mathrm{t} 2}\right]\left[\frac{\widetilde{v}}{\mathrm{~d}}\right]^{2}$ is the destruction term of turbulent viscosity and $f_{t 1}(\Delta q)^{2}$ is the trip term which is generally ignored when performing fully turbulent analysis.

\subsubsection{SST $k$ - $\omega$ turbulence model}

The shear stress transport (SST) k- $\omega$ turbulence model is two-equation model and it is combination of Standard k- $\omega$ model and Standard k- $\omega$ model [20]. This turbulence model is suitable to simulate the boundary layer and complex turbulent flow field that includes unsteadiness and separation. The disadvantage of this model is difficult to converge and requires good mesh solution near the wall so; it may need high computational time and power requirement. The SST k- $\omega$ turbulence model is defined as following Equations (5) and (6).

$$
\begin{aligned}
\frac{\partial}{\partial t}(\bar{\rho} k)+\frac{\partial}{\partial x_{j}}\left(\bar{\rho} \bar{u}_{j} k\right) & \\
= & \frac{\partial}{\partial x_{j}}\left[\left(\mu+\sigma_{k} \mu_{t}\right) \frac{\partial k}{\partial x_{j}}\right]+P_{k}-\beta \rho \omega k \\
\frac{\partial}{\partial t}(\bar{\rho} \omega)+\frac{\partial}{\partial x_{j}}\left(\bar{\rho} \bar{u}_{j} \omega\right) & \\
= & \frac{\partial}{\partial x_{j}}\left[\left(\mu+\sigma_{\omega} \mu_{t}\right) \frac{\partial \omega}{\partial x_{j}}\right] \\
& +2\left(1-F_{1}\right) \bar{\rho} \sigma_{\omega 2} \frac{1}{\omega} \frac{\partial k}{\partial x_{j}} \frac{\partial \omega}{\partial x_{j}}+\alpha \frac{\omega}{k} P_{k} \\
& -\beta \bar{\rho} \omega^{2}
\end{aligned}
$$

In Equation (5), $\mathrm{P}_{\mathrm{k}}$ (production of turbulence) and $\tau \mathrm{ij}$ can be defined as following Equations (7) and (8).

$$
\begin{gathered}
P_{k}=\tau_{i j} \frac{\partial u_{i}}{\partial x_{j}} \\
\tau_{i j}=\mu_{i}\left(\frac{\partial u_{i}}{\partial x_{j}}+\frac{\partial u_{i}}{\partial x_{j}}-\frac{2}{3} \delta_{i j} \frac{\partial u_{i}}{\partial x_{j}}\right)-\frac{2}{3} \rho k \delta_{i j}
\end{gathered}
$$

The constant $F_{1}$ that is available in Equation (6) is equal to 1 for the $\mathrm{k}-\omega$ model and it is equal to 0 for the $\mathrm{k}-\varepsilon$ model. Turbulent viscosity is defined as Equation (9) for SST k- $\omega$ model.

$$
v_{t}=\frac{0.31 k}{\max \left(0.31 w, \Omega F_{2}\right)}
$$

$\boldsymbol{\Omega}$ and $\mathrm{F}_{2}$ are defined by Equations (10) and (11) as follows.

$$
\Omega=\left|\frac{\partial v}{\partial x}-\frac{\partial u}{\partial y}\right|
$$

$$
F_{2}=\operatorname{Tanh}\left\{\left[\max \left(2 \frac{\sqrt{k}}{0.09 w y}, \frac{500 v}{w y^{2}}\right)\right]^{2}\right\}
$$

\subsubsection{Standard $k$-E turbulence model}

The Standard $\mathrm{k}-\varepsilon$ turbulence model $(\mathrm{k}$ is kinetic energy and $\varepsilon$ is turbulent dissipation) includes two transport equations. They account for diffusion of turbulent energy and convection. The $\mathrm{k}-\varepsilon$ turbulence contain some immeasurable and unknown terms. Therefore, in order to obtain practical approach, the Standard k- $\varepsilon$ model is used to minimize the unknowns and present the equations that can be used for turbulent flow $[21,22]$. This model is convenient to use under strong adverse pressure gradient, recirculation and separation [23].

The turbulent kinetic energy $\mathrm{k}$ and the turbulent dissipation $\varepsilon$ are defined in Equation (12) and Equation (13).

$$
\begin{gathered}
k=\frac{1}{2}\left[\bar{u}^{2}+\bar{v}^{2}+\bar{w}^{2}\right] \\
\varepsilon=v_{t} \frac{\overline{\partial u_{\imath} \partial u_{\imath}}}{\partial x_{j} \partial x_{j}}
\end{gathered}
$$

The standard $\mathrm{k}-\varepsilon$ two equations turbulence model is expressed in Equation (14) and Equation (15).

$$
\begin{gathered}
\rho \frac{d k}{d t}=\frac{\partial}{\partial x_{j}}\left[\left(\mu+\frac{\mu_{t}}{\sigma_{k}}\right) \frac{\partial k}{\partial x_{j}}\right]+P_{k}-\rho \varepsilon \\
\rho \frac{d \varepsilon}{d t}=\frac{\partial}{\partial x_{j}}\left[\left(\mu+\frac{\mu_{t}}{\sigma_{\varepsilon}}\right) \frac{\partial \varepsilon}{\partial x_{j}}\right]+c_{\varepsilon 1} P_{k} \frac{\varepsilon}{k}-c_{\varepsilon 2} \rho \frac{\varepsilon^{2}}{k}
\end{gathered}
$$

\subsubsection{Realizable $k$ - $\varepsilon$ turbulence model}

This turbulence model shows superior performance for boundary layer with strong adverse pressure gradient, the 
flow includes rotation, separation and recirculation. In addition, Realizable k- $\varepsilon$ has an ability to capture mean flow of complex structures. The Realizable k- $\varepsilon$ model is expressed as following Equations (16) and (17) [23, 24].

$$
\begin{aligned}
\frac{\partial}{\partial t}(\rho k)+\frac{\partial}{\partial x_{j}}\left(\rho k u_{j}\right) & \\
= & \frac{\partial}{\partial x_{j}}\left[\left(\mu+\frac{\mu_{t}}{\sigma_{k}}\right) \frac{\partial k}{\partial x_{j}}\right]+P_{k}+P_{b}-\rho \varepsilon \\
& -Y_{M}+S_{k} \\
\frac{\partial}{\partial t}(\rho \varepsilon)+\frac{\partial}{\partial x_{j}}\left(\rho \varepsilon u_{j}\right) & \\
= & \frac{\partial}{\partial x_{j}}\left[\left(\mu+\frac{\mu_{t}}{\sigma_{\varepsilon}}\right) \frac{\partial \varepsilon}{\partial x_{j}}\right]+\rho C_{1} S \varepsilon \\
& -\rho C_{2} \frac{\varepsilon^{2}}{k+\sqrt{v \varepsilon}}+C_{1 \varepsilon} \frac{\varepsilon}{k} C_{3 \varepsilon} P_{b}+S_{\varepsilon}
\end{aligned}
$$

Where

$$
C_{1}=\max \left[0.43, \frac{\eta}{\eta+5}\right], \quad \eta=S \frac{k}{\epsilon}, \quad S=\sqrt{2 S_{i j} S_{i j}}
$$

$\mathrm{P}_{\mathrm{k}}$ represents the generation of turbulence kinetic energy and $\mathrm{P}_{\mathrm{b}}$ is the generation of turbulence kinetic energy.

\subsubsection{RNG $k-\varepsilon$ turbulence model}

The RNG model that is developed by Yakhot et al. [25] is a mathematical technique which is utilized to derive turbulence model. This method is renormalized the NavierStokes equations to be able to account the effect of smaller motion. The transport equation of RNG k- $\varepsilon$ can be expressed as following Equations (18) and (19).

$$
\begin{aligned}
\frac{\partial}{\partial t}(\rho k)+\frac{\partial}{\partial x_{i}}\left(\rho k u_{i}\right) & =\frac{\partial}{\partial x_{j}}\left[\left(\mu+\frac{\mu_{t}}{\sigma_{k}}\right) \frac{\partial k}{\partial x_{j}}\right]+P_{k}-\rho \varepsilon \\
\frac{\partial}{\partial t}(\rho \varepsilon)+\frac{\partial}{\partial x_{i}}\left(\rho \varepsilon u_{i}\right) & \\
& =\frac{\partial}{\partial x_{i}}\left[\left(\mu+\frac{\mu_{t}}{\sigma_{\varepsilon}}\right) \frac{\partial \varepsilon}{\partial x_{i}}\right]+C_{1 \varepsilon} \frac{\varepsilon}{k} P_{k} \\
& +C_{2 \varepsilon}^{*} \rho \frac{\varepsilon^{2}}{k}
\end{aligned}
$$

Where,

$$
\begin{gathered}
C_{2 \varepsilon}^{*}=C_{2 \varepsilon}+\frac{C_{\mu \eta^{3}}\left(1-\eta / \eta_{0}\right)}{1+\beta \eta^{3}} \\
\eta=S k / \varepsilon \\
S=\left(2 S_{i j} S_{i j}\right)^{1 / 2}
\end{gathered}
$$

\section{Geometry and mesh generation}

The simplified ground body dimensions are presented in Figure 1 adapted from Ahmed et al. [1]. Geometry of the body is formed using Designmodeler in ANSYS. The solid model of Ahmed body is presented in Figure 2. In this study, the slant angle of rear face is $35^{\circ}$ for all analysis. The selected body is modified by applying fixed radius blend with $25 \mathrm{~mm}$ for the upper sides of model. In addition, the second modification is implemented by applying chamfer to the sides of rear part with $50 \mathrm{~mm}$ and rounded rear underside of model with radius $25 \mathrm{~mm}$. The first and second modifications of model are presented in Figure 3 and Figure 4 , respectively.

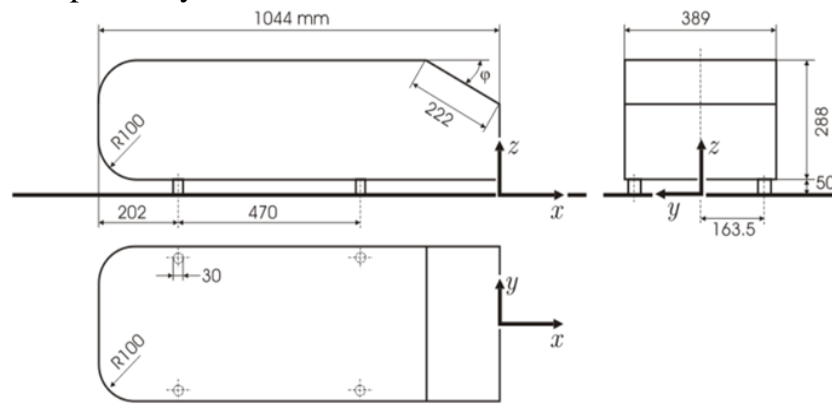

Figure 1. Ahmed body model (Dimensions are in $\mathrm{mm}$ ) $[1,26]$.

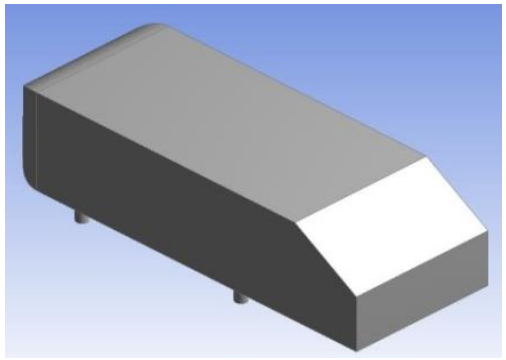

(a)

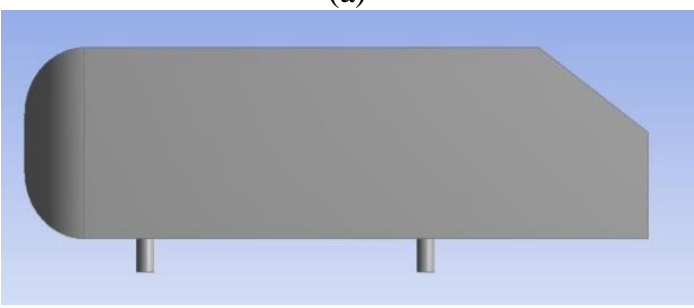

(b)

Figure 2. Solid model of Ahmed body (a: isometric view, b: side view)

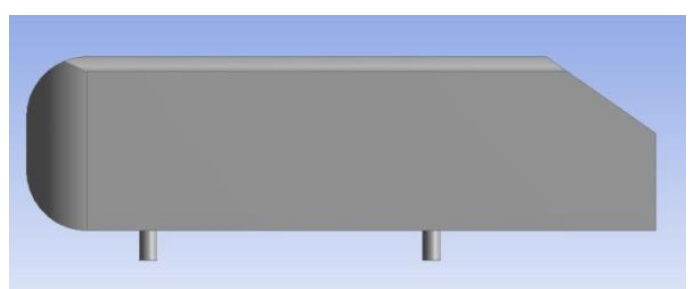

(a)

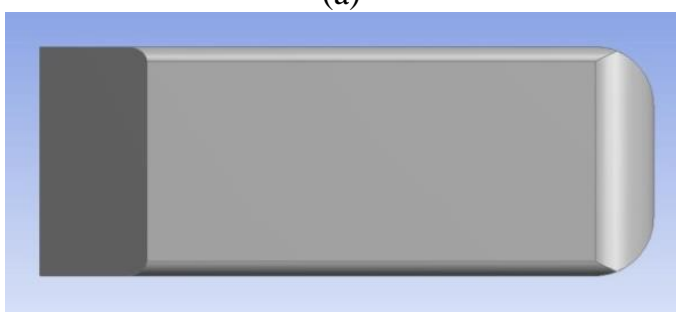

(b)

Figure 3. Solid model of first modification of Ahmed body (a: side view, b: top view) 


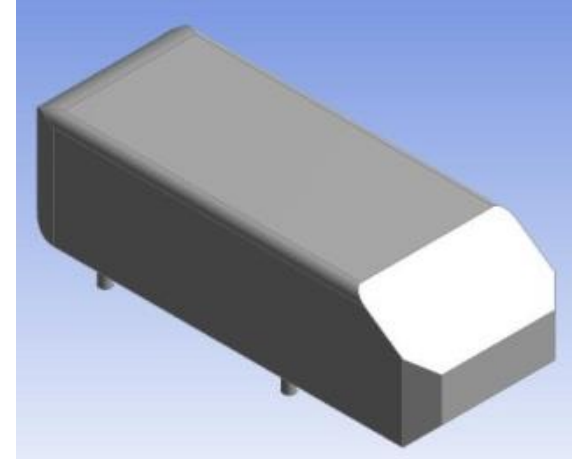

(a)

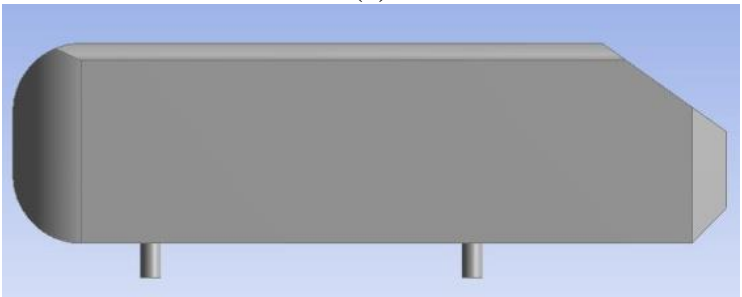

(b)

Figure 4. Solid model of second modification of Ahmed body (a: isometric view, b: side view)

Mesh generation is performed using Mesh ANSYS. The mesh process is crucial issue to obtain precision results. Solution gradients are often high in the vicinity of bodies in the external aerodynamic solutions. In order to help capture these gradients, inflation control is applied to obtain finer mesh generation for solution of boundary layer. The structured mesh is formed around the body using 20 prismatic layers and tetrahedral mesh is formed in the remaining part of the computational fluid domain. The mesh generation for body and computational fluid domain are presented in Figure 5 and 6, respectively.

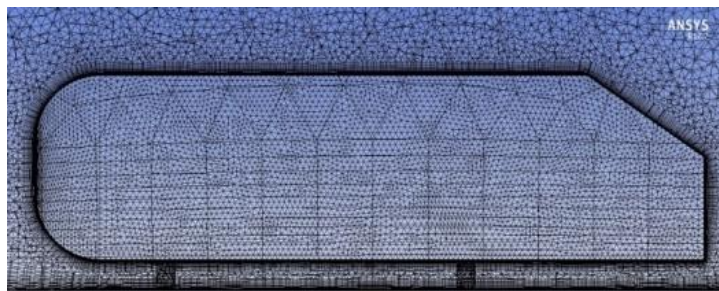

Figure 5. Mesh generation around the Ahmed Body

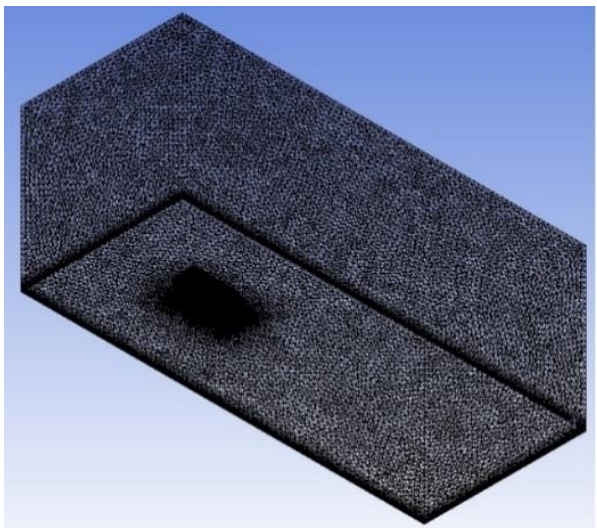

Figure 6. Mesh generation of computational domain

Mesh independency/sensitivity should be considered to find convenient mesh structure and mesh number. This process is also important in point of saving computational time and power requirement. Therefore, mesh generation is repeated eleven times for different mesh numbers that started from about 200000 up to 6 million. The drag coefficient values are investigated and it is concluded that the change of values are negligible small after mesh number is more than 2301000. The mesh independency chart versus drag coefficient is presented in Figure 7.

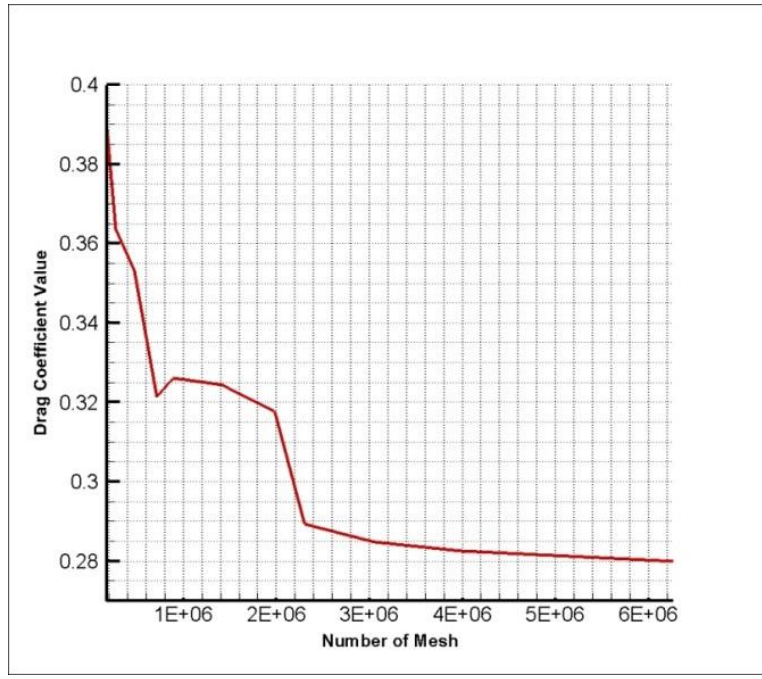

Figure 7. Mesh independency chart

\section{Computational setup and boundary conditions}

In this study, the CFD solution is performed using Fluent ANSYS which uses finite volume method. The Ahmed body and road is defined as wall type due to no-slip condition. The enclosure surfaces are defined as symmetry during the solution. The inlet and outlet plane are defined velocity-inlet and pressure outlet for boundary conditions, respectively. Computational fluid domain is formed as a rectangular shape and its length is 12 times of body length. The height and wide of the fluid domain are 10 times of the body height and wide, respectively. This boundary condition is more suitable in terms of saving time and power requirement.

The implicit formulation with Roe-FDS flux type is selected for solution method and second order upwind is defined for flow. The solver type is defined as density based and steady-state for computation of flow field. Courant number that is a dimensionless number represents the time a particle stays in cell of mesh and it is determined as 0.7 . The wall function is selected as enhancement wall treatment that is a near wall modeling method, for Standard, Realizable and RNG k- $\varepsilon$ turbulences model. The wall function is not used Spalart-Allmaras and SST k- $\omega$ turbulence model. The dimensionless wall distance value is about $\mathrm{y}^{+} \approx 1$ to capture flowfield in boundary layer. This value is greater than 1 in some place. In order to find accurate results, the flow residuals are tracked and when their values reach to $10^{-5}$ and 
the change of aerodynamic coefficient value is smaller than $1 \%$, the computation run is finished.

In this study, the solutions are performed at $40 \mathrm{~m} / \mathrm{s}$ and Reynolds number which is based on model's length is $2.78 \times 10^{6}$. Air density is $\rho=1.225 \mathrm{~kg} / \mathrm{m}^{3}$ and dynamic viscosity is $\mu=1.789 \times 10^{-5}$. CFD solutions are carried out using five different turbulence models for specified boundary conditions and computational set up.

\section{Result and Discussion}

In this study, five different turbulence models that are Spalart-Allmaras, SST k- $\omega$, standard k- $\varepsilon$, realizable k- $\varepsilon$ and RNG k- $\varepsilon$ are used to simulate the flow around the Ahmed body. For this study, it can be stated that the flow is fully turbulent due to higher Reynolds number. These selected turbulence models are suitable for steady flow and simulate the fully turbulent flow regime well. The solution results show that RNG $\mathrm{k}-\varepsilon$ turbulence model gives better result when compare with experimental data reported in the literature. Drag coefficient values of CFD solutions and their differences between the experimental results and solutions are given in Table 1 for each turbulence model.

Table 1. Drag coefficient values and their differences between experimental results and solutions for each turbulence models

\begin{tabular}{llc}
\hline Turbulence Model & $\mathbf{C}_{\mathbf{D}}$ Value & $\begin{array}{c}\text { Differences } \\
(\boldsymbol{\%})\end{array}$ \\
\hline Spalart-Allmaras & 0.362 & 29.74 \\
SST k- $\omega$ & 0.3401 & 21.89 \\
Standard k- $\varepsilon$ & 0.3283 & 17.67 \\
Realizable k- $\varepsilon$ & 0.303 & 8.60 \\
RNG k- $\varepsilon$ & 0.281 & 0.71 \\
Experimental result [6] & 0.279 & - \\
\hline
\end{tabular}

The modifications are applied to the Ahmed model and CFD solution is repeated using RNG k- $\varepsilon$ turbulence model. The first modification is rounded the upper sides of model with $25 \mathrm{~mm}$ fixed blend radius and the drag coefficient is reduced about $6 \%$. The second modification is performed to apply chamber to rear sides of model and rounded the underside of rear of model. The reduction of drag coefficient level is not significantly observed when compared with first modified model. The representation of drag coefficient levels is given in Figure 8.

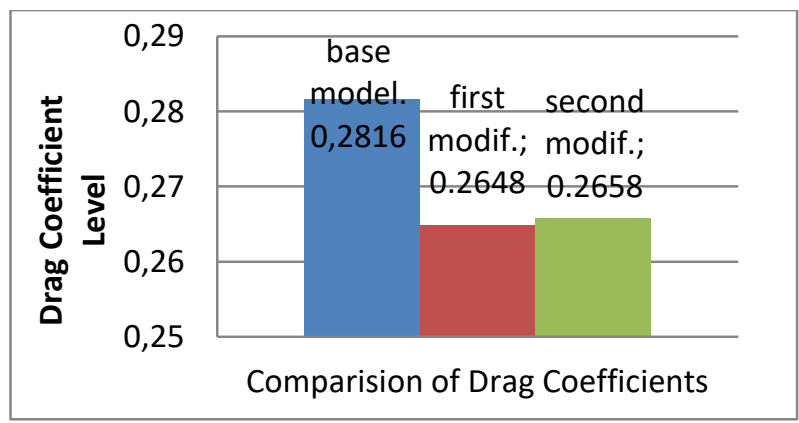

Figure 8. Comparison of drag coefficients level for base and modified models

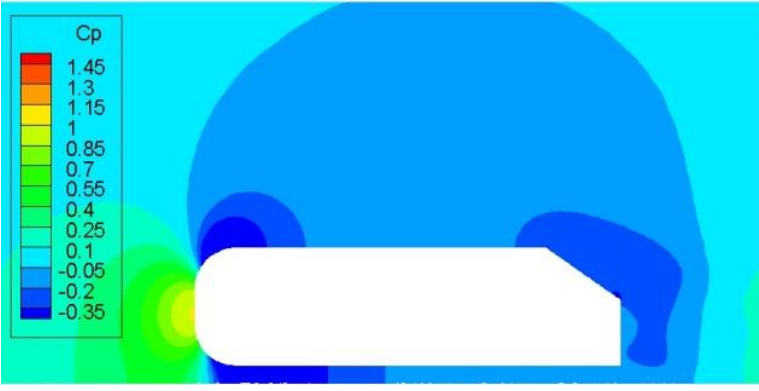

(a)

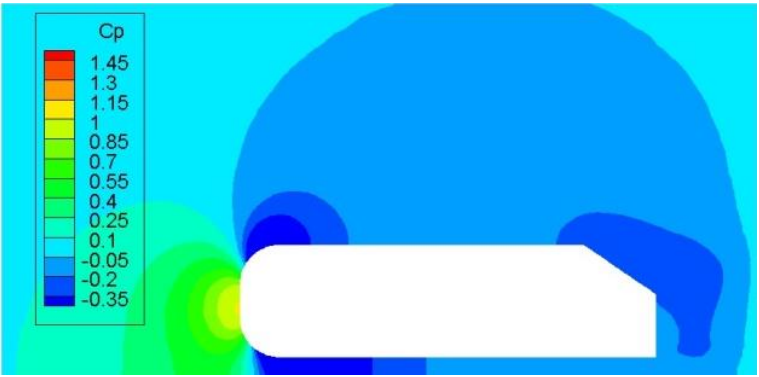

(b)

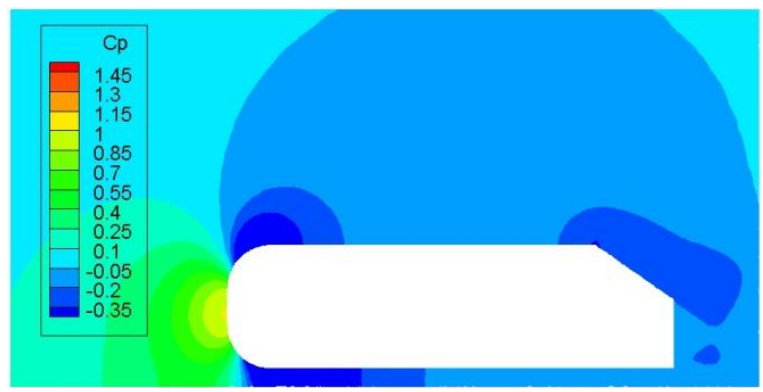

(c)

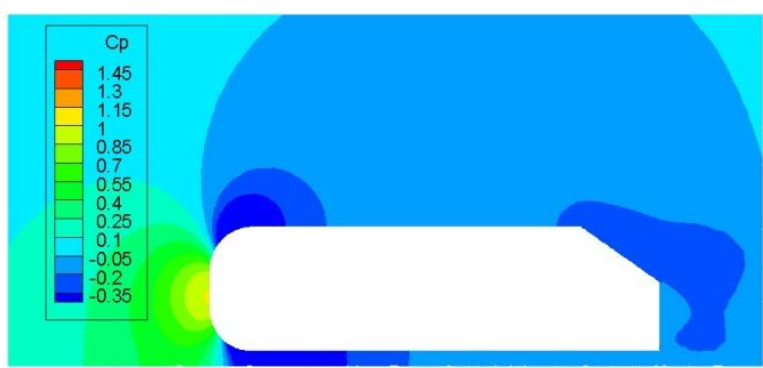

(d)

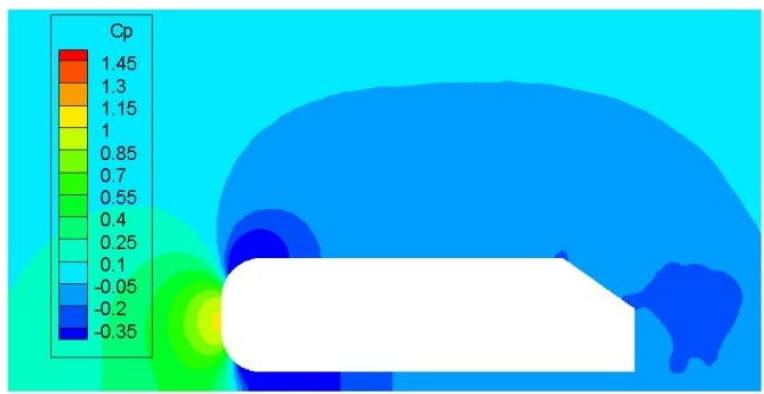

(e)

Figure 9. Pressure Coefficient Contour of Ahmed Body (a: Spalart-Allmaras, b: SST k- $\omega$, c: Standard k- $\varepsilon$, d: Realizable k- $\varepsilon$, e: RNG k- $\varepsilon$ Turbulence Models) 


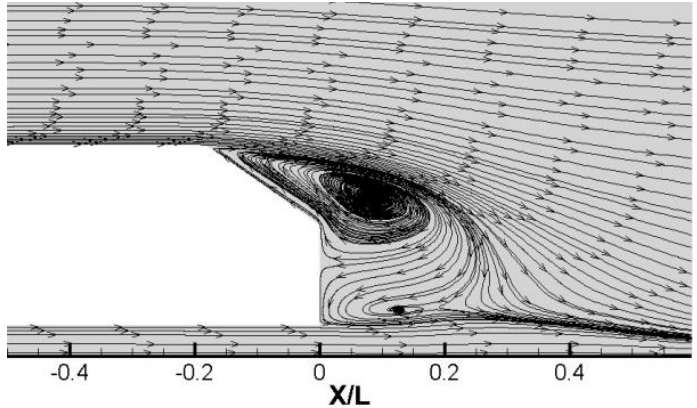

(a)

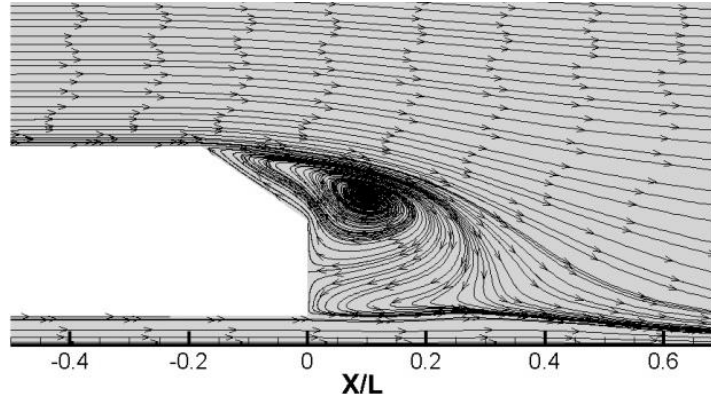

(b)

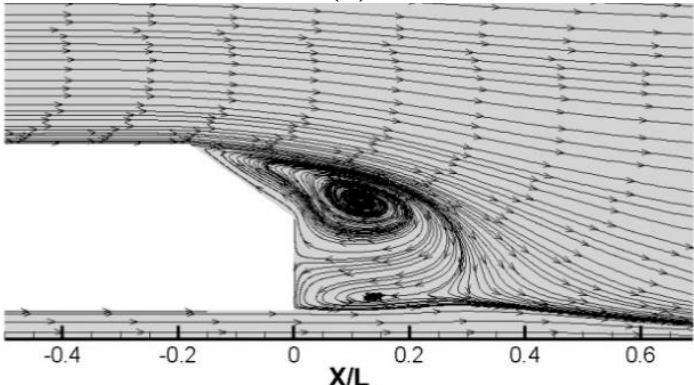

(c)

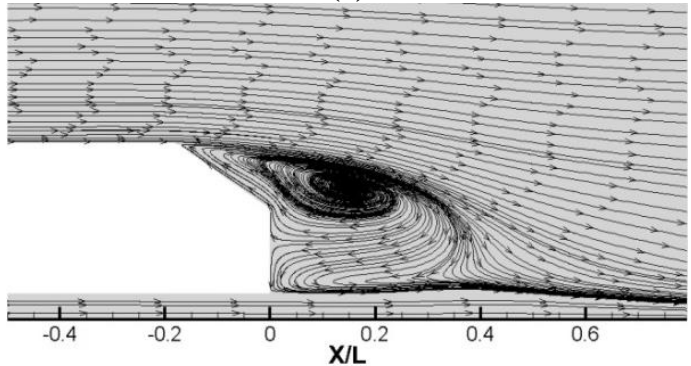

(d)

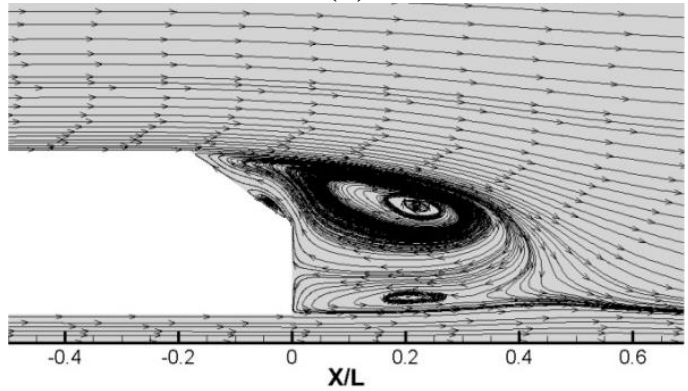

(e)

Figure 10. Velocity Streamlines of Ahmed Body (a: SpalartAllmaras, b: SST k- $\omega$, c: Standard k- $\varepsilon$, d: Realizable k- $\varepsilon$, e: RNG k- $\varepsilon$ Turbulence Models)
Pressure coefficient contours are presented for each turbulence model in Figures 9. When all figures are examined, it can be observed that the pressure coefficient is very low at slanted surface of rear region of model. The smallest pressure value occurs for Spalart-Allmaras turbulence model when compared with others. Therefore, it can be stated that drag coefficient value is high since pressure difference is high between the front part region and rear part region for Spalart-Allmaras model when compared with other models. It is concluded that the RNG k- $\varepsilon$ turbulence model is the best simulation of flow around Ahmed body since it can capture flow field and gives the closer results when checked against the experimental data.

Velocity streamlines are also presented to show flow regime at rear region of the Ahmed model in Figures 10. The vortex forms in this region and when compared to each other, it can be observed that the vortex formation occurs further behind for RNG k- $\varepsilon$ turbulence model.

The pressure coefficient contours are also presented for modified bodies. The Figure 11 shows the first modification and second modification bodies. There is no significantly difference among these two figures in point of flow characteristic. However, if these are compared with pressure coefficient contours of baseline body, it can be said that the lower pressure area is reduced and this may enable to reduce drag coefficient level. In addition, in order to reduce drag coefficient and prevent the separation of flow in the rear part region of body, it can be rounded upper part of slanted surface and added active or passive device since low pressure area separation of flow occur around the slanted surface of body. In addition, the velocity streamlines are given in a plane perpendicular the flow at the rear region of model in Figure 12. The vortex formation can be seen for the base model but not for the modified model. Hence, it can be stated that the modified model is more efficient than base model in point of aerodynamics.

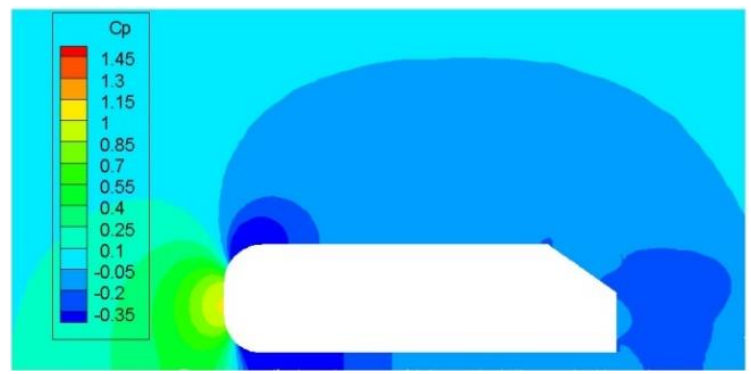

(a)

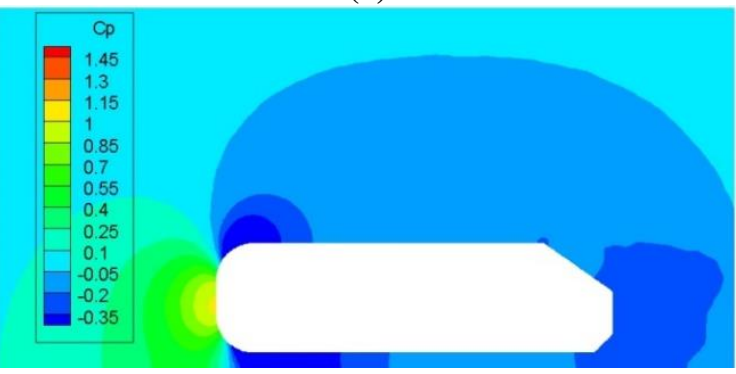

(b)

Figure 11. Pressure Coefficient values of Ahmed Body (a: First Modified body b: Second modified body) 


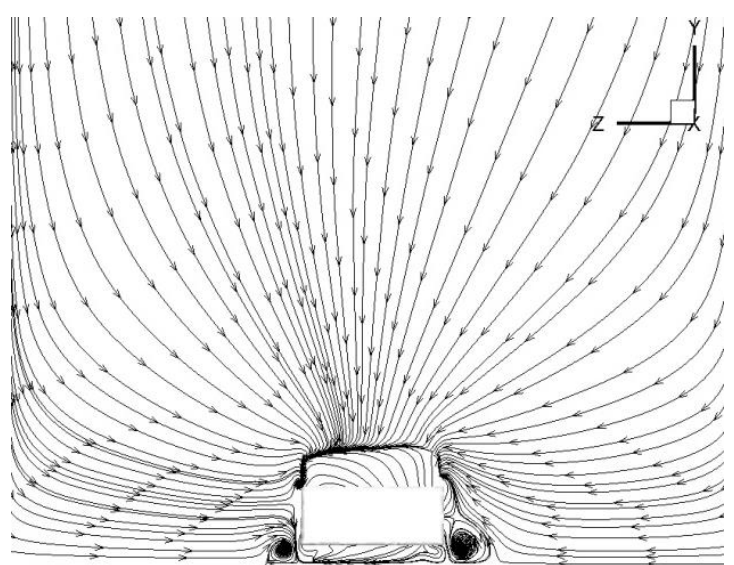

(a)

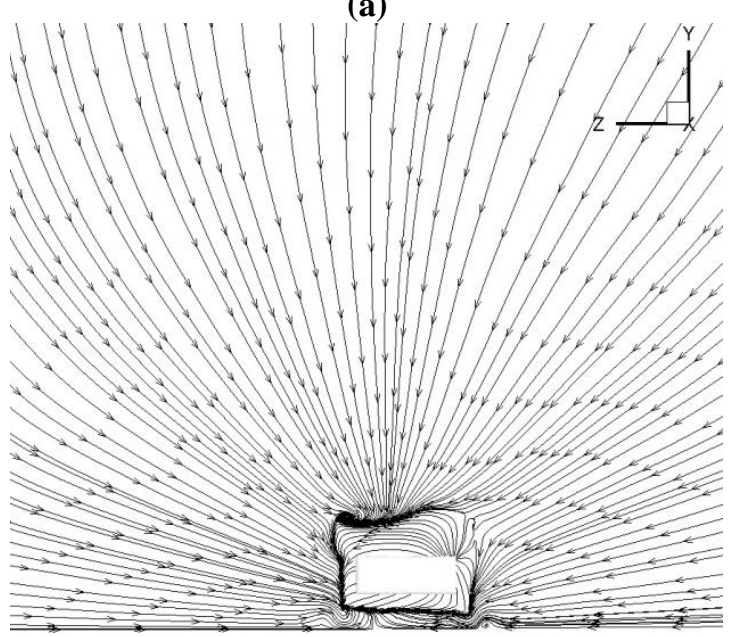

(b)

Figure 12. Velocity Streamlines at rear region of Ahmed Body (a: Base Body b: Second Modified Body)

\section{Conclusion}

In this study, the generic simplified ground vehicle that is called Ahmed body was investigated in terms of aerodynamic. For this, five different turbulence models were used to find which turbulence model is more suitable to simulate flow around the body. The CFD solutions were repeated for each turbulence model and checked against to experimental data. The results were showed that RNG k- $\varepsilon$ turbulence model gave closer results to experimental data. In addition, the Ahmed body was modified to reduce drag coefficient. The first modification was implemented to apply fixed blend radius upper sides of body by rounding with 25 $\mathrm{mm}$. The second modification was performed by applying fixed blend radius with rounded both upper sides and rear underside of body and chamfer with $50 \mathrm{~mm}$ was applied to rear sides of body. It was concluded that the drag coefficient reduced about $6 \%$ for first modified body. However, second modified body was not significantly observed for reduction of drag coefficient level when compared with first modification model. The table and pressure coefficient contours were presented for the turbulence models. Pressure coefficient contours and velocity streamlines were also presented to indicate differences between base and modified bodies. The further study can be performed by using passive and active flow control devices and rounding upper side of slanted surface.

\section{Conflict of interest}

There is no conflict of interest.

\section{Similarity index (iThenticate): $\% 7$ \\ References}

[1] S. R. Ahmed, G. Ramm, and G. Faltin, Some salient features of the time-averaged ground vehicle wake. SAE Transactions, 473-50, 1984. https://doi.org/ $10.4271 / 840300$

[2] S. R. Ahmed, Wake structure of typical automobile shapes. Transaction of the ASME, 162-169, 1981. https://doi.org/10.1115/1.3240767

[3] S. R. Ahmed, Influence of base slant on the wake structure and drag of road vehicles. Journal of Fluid Engineering, 429-434, 1983. https://doi.org/10.1115/ 1.3241024

[4] R. S. Khan, and S. Umale, CFD aerodynamic analysis of Ahmed body. International Journal of Engineering Trends and Technology, 18(7), 301-308, 2014. doi:10.14445/22315381/IJETT-V18P262

[5] C. A. Gilkeson, V. V. Toropov, H. M. Thompson, M. C. T. Wilson, N. A. Foxley, and P. H. Gaskell, Dealing with numerical noise in CFD-based design optimization. Computers and Fluids, 94, 84-97, 2014. https://doi.org/10.1016/j.compfluid.2014.02.004

[6] W. Meile, G. Brenn, A. Reppenhagen, B. Lechner, and A. Fuchs, Experiments and numerical simulations on the aerodynamics of the Ahmed body. CFD letters, 3(1), 32-39, 2011.

[7] J. Östh, B. R. Noack, S. Krajnović, D. Barros, and J. Borée, On the need for a nonlinear subscale turbulence term in POD models as exemplified for a highReynolds-number flow over an Ahmed body. Journal of Fluid Mechanics, 747, 518-544, 2014. https://doi. org/10.1017/jfm.2014.168

[8] R. Volpe, P. Devinant, and A. Kourta, Experimental characterization of the unsteady natural wake of the full-scale square back Ahmed body: Flow bi-stability and spectral analysis. Experiments in Fluids, 56(5), 99, 2015. https://doi.org/10.1007/s00348-015-1972-0

[9] V. K. Yakkundi, and S. S. Mantha, CFD Analysis of flow over car variants and validation with Ahmed body. CURIE Journal, 3(1), 2010.

[10] S. Thabet, and T. H. Thabit, CFD simulation of the air flow around a car model (Ahmed body). International Journal of Scientific and Research Publications, 8(7), 517-525, 2018. http://dx.doi.org/10.29322/IJSRP. 8.7.2018.p7979

[11] T. Tunay, E. Firat, and B. Sahin, Experimental investigation of the flow around a simplified ground vehicle under effects of the steady crosswind. International Journal of Heat and Fluid Flow, 71, 137152, 2018. https://doi.org/10.1016/j.ijheatfluidflow. 2018.03.020

[12] T. Tunay, L. Drugge, and C. J. O’Reilly, On coupling methods used to simulate the dynamic characteristics of heavy ground vehicles subjected to crosswind. Journal 
of Wind Engineering and Industrial Aerodynamics, 201, 104194, 2020. https://doi.org/10.1016/j.jweia. 2020.104194

[13] T. Tunay, B. Sahin, and V. Ozbolat, Effects of rear slant angles on the flow characteristics of Ahmed body. Experimental Thermal and Fluid Science, 57, 165-176, 2014. https://doi.org/10.1016/j.expthermflusci.2014. 04.016

[14] B. Zafer, and F. Haskaraman, Önden ve yanal rüzgar şartı altında Ahmed cisminin sayısal incelenmesi. Journal of the Faculty of Engineering and Architecture of Gazi University, 32(1), 2017. https://doi.org/ 10.17341/gazimmfd.300613

[15] F. J. Bello-Millan, T. Mäkelä, L. Parras, C. Del Pino, and C. Ferrera, Experimental study on Ahmed's body drag coefficient for different yaw angles. Journal of Wind Engineering and Industrial Aerodynamics, 157, 140-144, 2016. https://doi.org/10.1016/j.jweia.2016. 08.005

[16] C. Chovet, M. Feingesicht, B. Plumjeau, M. Lippert, L. Keirsbulck, F. Kerhervé, and J. M. Foucaut, Sliding mode control applied to a square-back Ahmed body. European Journal of Mechanics-B/Fluids, 81, 151-164, 2020. https://doi.org/10.1016/j.euromechflu.2019. 07.010

[17] H. Park, J. H. Cho, J. Lee, D. H. Lee, and K. H. Kim, Aerodynamic drag reduction of Ahmed model using synthetic jet array. SAE International Journal of Passenger Cars-Mechanical Systems, 6(2013-010095), 1-6, 2013. https://doi.org/10.4271/2013-010095

[18] S. Banga, M. Zunaid, N. A. Ansari, S. Sharma, and R. S. Dungriyal, CFD simulation of flow around external vehicle: Ahmed body. IOSR Journal of Mechanical and Civil Engineering, 12(4), 87-94, 2015. http://dx.doi.org/10.9790/1684-12438794

[19] P. R. Spalart, and S. R. Allmaras, A one-equation turbulence model for aerodynamic flows, AIAA, 920439, 1992. https://doi.org/10.2514/6.1992-439

[20] F. R. Menter, Two-equation eddy-viscosity turbulence models for engineering applications, AIAA journal, 32, 1598-1605, 1994. https://doi.org/10.2514/3.12149

[21] B. E. Launder, and B. I. Sharma, Application of the energy-dissipation model of turbulence to the calculation of flow near a spinning disc. Letters in heat and mass transfer, 1(2), 131-137, 1974. https://doi.org/ 10.1016/0094-4548(74)90150-7

[22] B. E. Launder, and D. B. Spalding, The numerical computation of turbulent flows. Numerical prediction of flow, heat transfer, turbulence and combustion 96116, 1983. https://doi.org/10.1016/B978-0-08-0309378.50016-7

[23] Fluent, A.N.S.Y.S. ANSYS Fluent 12.0 Theory Guide. ANSYS Inc., Canonsburg, PA. 2009.

[24] D. C. Wilcox, Turbulence modeling for CFD. Vol. 2, 103-217, 1998. La Canada, CA: DCW industries.

[25] V. Yakhot, S. A. Orszag, S. Thangam, T. B. Gatski, and C. G. Speziale, Development of turbulence models for shear flows by a double expansion technique. Physics of Fluids A: Fluid Dynamics, 4(7), 1510-1520, 1992. https://doi.org/10.1063/1.858424

[26] C. Hinterberger, M. Garcia-Villalba, and W. Rodi, Large eddy simulation of flow around the Ahmed body. The aerodynamics of heavy vehicles: trucks, buses, and trains, 77-87, 2004. Springer, Berlin, Heidelberg. 